\title{
A Journey Back Home: Lived Experience of the Returning Overseas Filipinos in a 14-Day Quarantine Facility
}

\author{
Carie Justine P. Estrellado \\ University of the Philippines Open University \\ Laguna, Philippines
}

\section{Marlon V. Bunyi}

Philippine Christian University

Manila, Philippines

\author{
Myla M. Arcinas, PhD \\ De La Salle University \\ Manila, Philippines
}

\begin{abstract}
In outbreak prevention and infection control amid the COVID-19 pandemic, the Philippine government mandated the returning Overseas Filipino Workers (OFWs) to undergo a 14-day quarantine and isolation upon arrival in the country. In this light, this study utilized Heideggerian existential phenomenology to describe the experiences of OFWs in the quarantine facilities and the meanings they associated with their 14-day quarantine experience. Six purposively selected OFW-informants participated in the study. From the findings, five main themes emerged: (1) concerns and challenges of uncertainties, (2) emotional struggles, (3) process of coping, (4) meanings associated with their quarantine experience, and (5) their trusts and hopes. This study recommends a strengthened psycho-social support program to manage distress among OFWs and provide information and services needed to mount an appropriate response to assisting OFWs in this pandemic.
\end{abstract}

Keywords: COVID-19; Overseas Filipino Workers; Quarantine; Phenomenology

\section{Introduction}

Around 10 million Filipinos are working abroad, commonly known as Overseas Filipino Workers (OFWs). The OFWs have been badly affected by the COVID-19 pandemic as many businesses abroad were forced to close down and terminated their contracts. The situation brought devastation to almost all nations' economies and business sectors, leading some businesses to close while others permanently halted. The dire socio-economic impact led to the influx of OFWs hoping to return to their home country. According to the statements of Labor Secretary Silvestre Bello III, " 343,551 OFWs have been affected by the pandemic, but close to projected 200,000 are opting to remain overseas, hoping to find employment where they are once the situation improves, but some decided to fly back home" (Phelan, 2020; Ramos, 2020, as cited in Asis, 2020). Subsequently, with the surge of OFWs returning to the Philippines, they also face another ordeal. OFWs returning home need to comply with the strict protocols set by the Inter-Agency Task Force on the management of Emerging Infectious Diseases (IATF-EID). OFWs need to subject themselves to mandatory reverse-transcription polymerase chain reaction (RT-PCR) tests and a fourteen-day quarantine in any government-approved facilities. 
From this condition, there are reasons why the intervention quarantine is likely to harm the mental health of the sick, surmising from the pandemic. It will be difficult for those who are quarantined to make sure they have enough food and other everyday needs (DiGiovanni et al., 2004). If people lack access to the necessities of this social system, they could become highly sensitive, nervous, irritable, or anxious (Maynard et al., 2019). People living in a society where quarantine is forced to stay within their homes will be more marginalized against or shunned than if the government were to quarantine a dying person (Karamouzian \& Hategekimana, 2015). Some studies stated that quarantining people can trigger a sense of shame, stigmatization and stimulate tension in an attempt to protect vulnerable persons (Desclaux et al. 2017; Robertson et al. 2004; Xiang, 2020); can likewise trigger stress and anxiety, which can be further disturbed by the absence of financial support, lack of access to information, and prolong isolation (Brooks et al. 2020). Also, alienation and distress living in the isolation unit complain concerning unpleasant impacts on their lives; they feel like they have lost their individuality (Wang et al. 2011). Further, it can trigger long-term behavioral changes during the quarantine period, such as cautious handwashing and limiting social interactions (Cava et al. 2005); quarantine may be effectively cuts-off an infectious individual from spreading to others but with drawbacks to the mental health of a person (Locke et al. 2019).

The quarantine was set to observe and monitor the OFWs for any symptoms of the COVID-19 virus as they also wait for the results of their RT-PCR test. "Though quarantine is intended to protect the health of individuals from viral agents, it has been generally considered an undesirable experience that can cause various problems such as depression, anxiety, fear, isolation, anger, and uncertainty" (Lin et al. 2010).

This study sought to explore the lived experiences of the returning OFWs during their 14day quarantine, anchoring the analysis to the Heideggerian existential phenomenology, specifically guided by the following queries:

1. What challenges were experienced by returning OFWs during their 14-day quarantine period?

2. What meanings were associated by the returning OFWs with their 14-day quarantine experience?

\section{Method}

This study used the Heideggerian existential-phenomenological approach, a qualitative interpretive design, that explains the significance of a phenomenon's lived experience. It seeks to understand a phenomenon's nature by studying it from the viewpoint of those who have encountered it, based on the life of the human being as a person and within their social context in their society (Koch, 1999; Quick \& Hall, 2015). As such, analyzing the point of views, meanings, reflections of standpoint ideal of being in the universe with others, in common humanity, and in shared world experiences in the grounded context (Heidegger, 1927; 2011), wherein, for this case, is the experience of returning OFWs in quarantine facilities is the focal point of the study. The researchers utilized the purposive sampling technique from the six (6) returning OFWs of Candelaria, Quezon Province, four (4) of which were women and two (2) were men. The identified informants worked for at least three (3) years abroad (three were from the Middle East, two from Taiwan, and one from Europe), and all were identified as land-based migrant workers.

After accepting the informed consent, the researchers carried out semi-structured online interviews, ranging from 45 to 50 minutes via Messenger or Google Meet and a peer debriefing afterward. The transcribed video interviews were then analyzed using the cutting-and-sorting process (Green et al. 2007), then, the results were verified by the corresponding participant in each empirical report to unfold the emerging themes from their lived experiences of OFWs. Data collection occurred over three months, from August 2020 to October 2020. 


\section{Results and Discussion}

From the narrative interviews of the six informants, the researchers were able to generate five themes: 1. concerns and challenges of uncertainties, 2. emotional struggles, 3. process of coping, 4. perceived meaning, and 5. trust and hope.

\section{Theme 1}

\section{Concerns and challenges of uncertainties (CCU)}

Inconsistencies in the process. The lived experiences of the informants had issues on the processing stage of their arrival up to being quarantined. The struggle includes the processing of documents they needed to comply with as arriving OFWs subject to quarantine. Some informants revealed concerns about the long waiting time to process the custom check clearance and the requirements.

Interviewee No. 1, who was a nurse from the United Kingdom, stated:

"Hirap at matagal ang oras ng screening. Matagal talagang mag-aantay. Mabirap ang proseso ng documents tulad ng health declaration hanggang arrival" [The screening takes a long time and very rigid. We waited for long hours before we got out turn. It takes time to process the documents, such as the health declaration, until the arrival].

Interviewees No. 4 and 6 also shared a similar experience, stating, respectively:

"Remote experiences are, of course, difficult lalo sa processing ng papers" [Remote experiences are, of course, difficult, especially processing papers].

"We were challenged by longer cues and canceled flights. 'Di namin alam kapag natapos ang lahat ng ito ay babalik sa normal. Hindi ko mawari ang ating kalagayan" [We were challenged by longer cues and canceled flights. We do not know if everything will get back to normal once this is all done. I cannot understand our situation].

Interestingly, these were evident from Gotinga and Tomacruz's (2020) article that the OFWs have stagnated in a lengthy government quarantine, requirements process for about two weeks. Informants 4 \& 6 have told of problems and funding issues that have kept other OFWs in quarantine for much more than the required two-week duration and subjected them to the risk of contracting the virus. Additional issues raised while they were in 14-day quarantine were providing access to information, checking the test result, and securing a certificate for quarantine.

Problems with quarantine facilities. A considerable part of the isolation period for these OFWs was the quarantine facilities that the government has prepared for them to utilize. They shared concerns regarding their quarantine facilities, with one respondent describing the facility assigned to him as "underutilized."

Personal safety. Informants have also expressed their concern over their safety, particularly with the uncertainty of waiting for their RT-PCR results. Some grew anxious thinking about the possibility of turning positive for the virus.

Discrimination. The informants have also stated several remarks on discrimination issues as their concerns during their 14-day quarantine.

The concerns and challenges of uncertainties they encountered include the technical processing of requirements they needed to comply with as returning OFWs. They also experienced discrimination as part of being quarantined, concerns about personal safety, conditions of quarantine facilities, finances, and unemployment. 
Finances and unemployment are key to the challenges of returning OFWs. As Asis (2020) reported, a lack of jobs could occur when the employee fails to come back to work. The lack of jobs could occur because visa regulations do not travel directly back to the Philippines. Consequently, terminated their contracts included those whose terms had ended and or caught up by lockdowns. In comparison, repatriated OFWs experienced problems related to their papers or documents. They experienced delays in their stay in the quarantine area as they secure some required paperwork that would enable them to take care of the family and to be able to move to their family homes (Asis, 2020; Quijano, 2020).

Interviewee No. 2 stated:

"Kapag dito kasi sa atin magkakaroon pa ng discrimination. That way, kinakabahan ako baka kasi positive tapos madala ko sa aking pamilya at may-labeling pa sa amin" [We have discrimination here. So, I was scared I might be COVID-19 positive and carry it to my family, and I would be labeled in our area].

Similar concerns on discrimination were shared by Interviewees No. 4 and 5, the latter stating: "Hindi maayos ang briefing sa amin ng dumating kaming Manila. Parang takot sila at diri" [When we arrived in Manila, the briefing with us was not done well. They seem scared and disgusted].

Financial aspects and unemployment. Part of the informants' 14-day quarantine experience concerns their finances and uncertainty of employment afterward. Interviewee No. 2 stated:

"Trabaho ang number one urgent challenge kaya bago ako umuwi inaayos ko muna at inaalam ang pagbangon at paghanap ng trabaho na less risky" "Employment was the number one urgent challenge, so I already searched for less risky jobs here before traveling home].

Interviewee No. 4 highlighted his limited savings as his foremost concern during his quarantine period.

"Sobrang hirap nang pinagdaanan ko lalo at kaunti ang savings" [It was hard for me, especially that I do not have that much savings].

Meanwhile, Interviewee No. 6 emphasized concern for both finances and unemployment due to sick parents that need to be sustained and financed. Interviewee No. 6 thus stated:

"Gusto kong bumalik ulit sa abroad kasi wala ulit ako pangtustos sa mga magulang kong may sakit" II wanted to go back abroad since I cannot finance my sick parents].

\section{Theme 2}

\section{Emotional Struggles (ES)}

The informants went through emotional struggles during their quarantine period. They experienced fear, anxiety, boredom, while some manifested depressive symptoms, yearning for social normality.

Fear. Interviewees No. 2 and 3 mainly relayed fear as a dominant emotion during their quarantine period. Interviewee stated:

"Takot dabil hindi alam ang paroroonan kapag natapos ang quarantine. Lagi pati ako puyat at malungkot kahit na maganda ang room ko sa quarantine" [I was scared because I do not know what will happen after the quarantine. I was also sleep-deprived and sad despite having a beautiful room for quarantine].

Interviewee No. 3 also shared a similar experience, stating:

"Paano kung sa COVID-19 swab test eh it turned out positive? Then, will I be quarantined for another several days? Nakakapuyat din so far... Fear. Moreover, I am crying every day for the uncertainties. Who knows 
[what's] about to happen" [What if I am positive then I, again, will be quarantined for other several days? It was exhausting so far. I was scared. Moreover, I was crying almost everyday due to uncertainties. Who knows (what's) about to happen].

Anxiety. Stress has also taken its toll on the informants as they suffered anxiety. Interviewee No. 2 stated:

"Natutulala ako at tuliro. Sobrang stress ko" [I was often spaced out. I was so stressed].

The COVID-19 caused physical health issues, but it also leads to a variety of psychological pressures. The proliferation of viral disease will affect people's mental health in different stakeholders (Salari et al., 2020; Tee et al., 2020).

Interviewee No. 5 also remarked stress as a factor of having anxiety in quarantine, stating: "Nangangamba at ligalig sa stress. Malungkot ako lagi sa buong panahon ng quarantine" [I was worried and anxious due to stress. I was sad the whole quarantine period].

Likewise, Interviewee No. 6 stated:

"Iyak ako nang iyak. Kahit lalaki ako eh mahirap talaga and sitwasyon" [I was crying. Even for a man, it was a difficult situation.]

Boredom. Being alone in a room can also drive some to boredom, as the informants have also experienced. Interviewee No. 6, in particular, shared the experience, stating:

"Sa quarantine ay nakakainip ng todo kung wala kang lilibangin, dabil mag-isa ka" [Being in quarantine was boring without any form of leisure since you were alone].

Manifestations of depressive symptoms. With the real emotional struggle during their quarantine period, some informants have shown severe mental health concerns, such as depression. Interviewee No. 4 shared that he had several panic attacks while in quarantine and unable to cope with the situation. He shared:

I had daily panic attacks, standing on the wall, unable to walk or talk. It was a constant challenge to force myself to shower and perform simple self-care duties. I did not feel like eating or working out. I felt alone and trapped in the hotel. I had terrible dreams most nights. Thus, I refused to sleep. I just laid in bed and stopped responding to messages.

\section{Theme 3}

\section{Process of Coping (PC)}

The informants also shared how they coped with their situation, being in a quarantine facility for 14 days.

Positive reinterpretation. Some informants remained optimistic and chose to look at the situation in a brighter light. Interviewees No. 2 and 4, respectively, stated:

"Think positive, ika nga nila. Lahat naman ay may reasons at purpose sa labat ng nangyayari" [Think positive, as they say. All of this has reasons and purpose].

"I feel a lot better about a month later. I realize how hard this has to be, and it is worth noting that neither of us is alone. Things will improve after this pandemic. I spent time evaluating my life, thinking of my family and friends. Moreover, I prayed that this pandemic would soon pass. For now, all we can do is sit at home, take care of ourselves, our dear ones."

Interviewee No. 1 shared that despite the struggles, the accommodation was reasonable and their records were tracked regularly. 
"May daily records naman kami sa accommodation namin at welcoming naman ang mga staffs at frontliners" [We had daily records in our accommodation and the staff and frontliners were welcoming]. It then follows to divert to the highlight of basic health measures, especially regular handwashing using soap and water, and protocol such as healthy coughing and sneezing etiquette practice, emphasizing the value of careful primary health safeguards.

Holding on to one's faith. Some remained hopeful through prayers, as shared by Interviewees No. 1, 3, and 6. Interviewee No. 3 also shared that reading available books helped in the coping process, further stating:

"Focusing in reality, praying, and reaching out to others. I think the world is about to end, so it is time to repent the sins. All goodness and appreciation to our God."

The rising "prayer strength" manifests amid the pandemic; people worldwide feel and use confidence to cope with negative emotions. (Bentzen, 2020).

Interviewee No. 6 also coped with prayers, along with music and books.

"More on music and readings. Prayer is the most powerful tool sa akin" [More on music and readings. Prayer is the most powerful tool for me].

Sustaining communication with loved ones. Others coped by staying in communication with their family, as with the case of Interviewees No. 1, 2, and 5. Interviewee No. 1 stated:

"Hindi talaga pwede mawalan ng communications sa pamilya para malampasan ang krisis na ito." [The regular communication with the family should always be sustained to survive this crisis.]

Interviewee No. 2 also mentioned being updated with family and surfing on the internet like watching videos on YouTube.

"Panay nood ako youtube at update lagi sa pamilya" [I was always watching YouTube and exchanging updates with my family].

Interviewee No. 5 also emphasized the sceneries in their quarantine facility to help cope with the situation.

"Video call sa aking mga anak at panalangin na lahat ng pagsubok at dulot ay pagpapatibay. Maganda rin hotel namin kaya maraming views or sceneries na nakikita ko" [Video call with my kids and praying that all challenges will strengthen me. Our hotel was also lovely, so there were a lot of views or sceneries].

Asis (2016) has also revealed that some LGUs (Local Government Units) have restricted the return of OFWs (Overseas Filipino Workers) for fear that the OFWs may be carriers of the virus. As a result, they experienced emotional struggles that include fear, anxiety, and boredom, manifesting depressive behavior. The informants used prayers, positive interpretation of their experiences, and constant communication with family members to cope.

\section{Theme 4}

\section{Perceived Meaning (PM)}

The informants generated perceived meanings from their experiences during the 14-day quarantine.

Healthy lifestyle. Interviewee No. 2 stated that the experience led to the realization to maintain a healthy lifestyle and the need to follow protocols. Interviewee No. 2 stated: 
"Stay mentally and emotionally healthy lagi pati inom ng Vitamin C. Sunod sa health protocols kasi labat ng ginagawa namin ay para sa kanila (pamilya)" [Always stay mentally and emotionally healthy, and drink Vitamin C... Follow health protocols because we are doing all of this for our family].

Importance of family. Interviewees No. 3 and 5 also realized the importance of their family during their 14-day quarantine.

Spiritual connection. The quarantine experience also brought spiritual experience to the informants, as the experience brought them closer to God or their religious affinity. Interviewees No. 2 and 5, in particular, stated that their experience brought them closer to GOD or their religion.

The informants shared that their experiences during their 14-day quarantine made them assess and strengthen their spiritual health, a realization of the importance of a healthy lifestyle, and reconnect themselves to their family.

\section{Theme 5}

\section{Trust and Hope $(\mathrm{H})$}

Informants expressed high hopes and trust that the COVID-19 will soon end. This pandemic has affected the livelihood of many OFWs. Many countries closed their borders due to the fear of acquiring the virus-businesses likewise slow down. Informants No. 2 and 3 both expressed their wish for the pandemic to end. Interviewee No. 2 said:

"Matatapos din ang labat kapag nagkabakuna siguro kaya malakas pa rin ang pananalig ko at sana ay matapos nga itong laban ng bubay" [I believe everything will be good when the vaccine is finally available, my faith remains strong].

Interviewee No. 3 also shared, saying:

Hindi ako masaya sa sitwasyon, nakakapagod na lumaban habang naghibintay ng solusyon. Kaya nagtiwala na lang ako sa proseso. [I was not happy with the situation, but it tiresome to struggle as I waited for a solution. So, I just trusted the process]. For the society to return to normal. The COVID-19 pandemic affected the lives of most people in the world.

Interviewee No. 1 shared that she wishes for everything to go back to normal, stating that: "Sana, sa awa ng Diyos, ay bumalik na sa normal ang bubay dabil ako ang breadwinner sa pamilya so, kailangan din maghanap ng trabaho sa Pilipinas" [Hopefully, in God's mercy, everything will be back to normal since I am the breadwinner of the family, so I need to find a job here in the Philippines].

The informants set high hopes for the pandemic to end soon and for everything to return to normal for them to go back to their work as OFWs.

\section{Conclusion and Recommendations}

Five (5) themes from the 14-day quarantine experiences of the six OFW-informants emerged: 1. concerns and challenges of uncertainties (CCU), 2. emotional struggles (ES), 3. processes of coping (PC) 4. meanings (PM) of their experiences, and 5. their trusts and hopes $(\mathrm{H})$.

The concerns and challenges of uncertainties they encountered include the technical processing of requirements, discrimination as being labeled quarantined, concerns about personal safety, conditions of quarantine facilities, finances, and unemployment. 
Their emotional struggles vary and include fear of being alone, anxiety due to uncertainties, boredom due to lack of physical and social contact with the family members. As a result, they used different means to cope with their situation, including prayers, strengthening their spiritual health, and reconnecting to their family members. They set high hopes that this COVID-19 pandemic will soon end to go back to their work as OFWs.

This study recommends including psychosocial support to manage distress, providing information and services needed to mount an appropriate response since this report has significance for public health policies and experience in planning for potential public health issues. Moreover, future researchers may replicate and probe to cross-examine the experiences and perceptions of the OFWs in the quarantine facility with a large sample size compared to the local informants' lived experiences. A follow-up investigation is essential to see patterns and check variations in their experiences in terms of facilities, accommodation, treatment, and medical concerns.

Conflicts of Interest. The authors have no conflicts of interest to report.

\section{References}

Asis, M.M.B. (2020). Repatriating Filipino migrant workers in the time of the pandemic. International Organization for Migration. https:// publications.iom.int/system/files/pdf/mrs-63.pdf

Bentzen, J. S. (2020), "In Crisis, we Pray: Religiosity and the COVID-19 Pandemic", Covid Economics 20, CEPR

Brooks, S. K., Webster, R. K., Smith, L. E., Woodland, L., Wessely, S., Greenberg, N., \& Rubin, G. J. (2020). The psychological impact of quarantine and how to reduce it: rapid review of the evidence. The Lancet., 395, 912-920. https://doi.org/10.1016/S0140-6736(20)30460-8

Bureau Of Quarantine. (2020, April 2020). Memorandum Circular No. 2020-18. [Press Release]. https:// quarantine.doh.gov.ph/guidelines-for-the-use-of-cruise-ship-as-quarantine-facility/

Cava, M. A., Fay, K. E., Beanlands, H. J., McCay, E. A., \& Wignall, R. (2005). The experience of quarantine for individuals affected by SARS in Toronto. Public health nursing (Boston, Mass.), 22(5), 398-406. https://doi.org/10.1111/j.0737-1209.2005.220504.x

Department of Interior and Local Government. (2020, May). DILG orders PNP to set up help desks in police stations for stranded individuals. https://dilg.gov.ph/news/DILG-orders-PNP-to-set-up-helpdesks-in-police-stations-for-stranded-individuals/NC-2020-1161

Desclaux, A., Badji, D., Ndione, A. G., \& Sow, K. (2017). Accepted monitoring or endured quarantine? Ebola contacts' perceptions in Senegal. Social science \& medicine (1982), 178, 38-45. https://doi.org/10.1016/j.socscimed.2017.02.009

DiGiovanni, C., Conley, J., Chiu, D., \& Zaborski, J. (2004). Factors influencing compliance with quarantine in Toronto during the 2003 SARS outbreak. Biosecurity and Bioterrorism: Biodefense Strategy, Practice, and Science, 2(4), 265-272.

Dowling, M. (2007). From Husserl to van Manen. A review of different phenomenological approaches. International Journal of Nursing Studies, 44(1), 131-142. https:// doi.org/10.1016/j.ijnurstu.2005.11.026.

Gotinga, J.C. \& Tomacruz, S. (2020). OFWs struggle through prolonged quarantine in gov't 'VIP treatment.'https://www.rappler.com/newsbreak/in-depth/ofws-struggle-coronavirusquarantine

Green, J., Willis, K., Hughes, E., Small, R., Welch, N., Gibbs, L., \& Daly, J. (2007). Generating best evidence from qualitative research: The role of data analysis. Australian and New Zealand Journal of Public Health, 31(6), 545-550. https://doi.org/10.1111/j.1753-6405.2007.00141.x

Heidegger, M. (1927). Being and Time (Macquarrie, J., Robinson, E., Trans.). New York, NY: Harper \& Row.

Horrigan-Kelly, M., Millar, M., Dowling, M., (2016). Understanding the Key Tenets of Heidegger's Philosophy for Interpretive Phenomenological Research. https://journals.sagepub.com/doi/full/10.1177/1609406916680634 
Karamouzian, M., \& Hategekimana, C. (2015). Ebola treatment and prevention are not the only battles: understanding Ebola-related fear and stigma. International Journal of Health Policy and Management,4(1), 55-56.

Koch, T. (1999). An interpretive research process: Revisiting phenomenological and hermeneutical approaches. Nurse Researcher, 6, 20-34.

Liu, Q., et al. (2020). The experiences of health-care providers during the COVID-19 crisis in China: a qualitative study. Lancet Glob Health 2020. [PDF file]. https://www.thelancet.com/journals/langlo/article/PIIS2214-109X(20)30204-7/ fulltext

Locke, B., Low, M., \& Forsgren, E. (2019). An integrated management strategy to prevent outbreaks and eliminate infection pressure of American foulbrood disease in a commercial beekeeping operation. Preventive Veterinary Medicine, 167, 48-52.

Lu, H. (2020). Do Quarantine Experiences and Attitudes Towards COVID-19 Affect the Distribution of Mental Health in China? A Quantile Regression Analysis. The International Society for Quality-of-Life Studies. https://link.springer.com/article/10.1007/s11482-020-09851-0

Manlangit, M. (2020). The Hurting Heroes: The COVID-19 Crisis and Overseas Filipino Workers. The Diplomat. https://thediplomat.com/2020/05/the-hurting-heroes-the-covid-19-crisis-andoverseas-filipino-workers/

Maynard, M. S., Perlman, C. M., \& Kirkpatrick, S. I. (2019). Food insecurity and perceived anxiety among adolescents: an analysis of data from the 2009-2010 National Health and Nutrition Examination Survey (NHANES). Journal of Hunger \& Environmental Nutrition, 14(3), 339-351.

Nazario, D. (2020). For OFWs, going home amid pandemic is a very long journey. Manila Bulletin. https:// mb.com.ph/2020/09/13/for-ofws-going-home-amid-pandemic-is-a-very-longjourney/

Phelan, A. L., Katz, R., \& Gostin, L. O. (2020). The novel coronavirus originating in Wuhan, China: challenges for global health governance. JAMA, 323(8), 709710. https://doi.org/10.1001/jama.2020.1097

Quick, J., \& Hall, S. (2015). Part Two: Qualitative Research. Journal of Perioperative Practice, 25(7-8), 129_ 133. https://doi.org/10.1177/1750458915025007-803

Quijano, N., Fernandez, M. and Pangilinan, A. (2020). Misplaced Priorities, Unnecessary Effects: Collective Suffering and Survival in Pandemic Philippines. The Asia-Pacific Journal, [online] 18(16). $\quad$ https://apjjf.org/-Abbey-Pangilinan-Maria-Carmen-Ica-Fernandez-NastassjaQuijano/5435/article.pdf

Ramos, C.M. (2020). COVID-19 impact: DOLE sees 40\% drop in OFW remittances for 2020. Inquirer, 24 June.

Ranada, P. (2020). National gov't stops requiring PCR tests for locally-stranded individuals. Rappler. https://www.rappler.com/nation/national-government-no-longer-requiring-pcr-testcoronavirus-locally-stranded-individuals

Robertson, E., Hershenfield, K., Grace, S. L., \& Stewart, D. E. (2004). The psychosocial effects of being quarantined following exposure to SARS: a qualitative study of Toronto health care workers. The Canadian Journal of Psychiatry, 49(6), 403-407.

Salari, N., Hosseinian-Far, A., Jalali, R. et al. (2020). Prevalence of stress, anxiety, depression among the general population during the COVID-19 pandemic: a systematic review and metaanalysis. Global Health 16, 57. https://doi.org/10.1186/s12992-020-00589-w

Shaban, R., et al. (2020). SARS-CoV-2 infection and COVID-19: The lived experience and perceptions of patients in isolation and care in an Australian healthcare setting. American Journal of Infection Control.

Tee, M. L., Tee, C. A., Anlacan, J. P., Aligam, K., Reyes, P., Kuruchittham, V., \& Ho, R. C. (2020). Psychological impact of COVID-19 pandemic in the Philippines. Journal of affective disorders, 277, 379-391. https://doi.org/10.1016/j.jad.2020.08.043

The Philippine Consulate General. (2020, April 17). Public Advisory No.4 on COVID-19. [Press Release]. https://www.philembassy.no/newsroom/covid-19-public-advisory-no-14-links-to-officialsources-of-information-on-covid-19-in-the

Tomacruz, J. G. (2020). OFWs struggle through prolonged quarantine in gov't 'VIP treatment.' Rappler. https://www.rappler.com/newsbreak/in-depth/ofws-struggle-coronavirus-quarantine 
Wang, Y., Xu, B., Zhao, G., Cao, R., He, X., \& Fu, S. (2011). Is quarantine related to immediate negative psychological consequences during the 2009 H1N1 epidemic?. General hospital psychiatry, 33(1), 75-77. https://doi.org/10.1016/j.genhosppsych.2010.11.001

WHO. Coronavirus disease 2019 (COVID-19) situation report 93. World Health Organization, 2020. https://www.who.int/docs/default-source/coronaviruse/situation-reports/20200422-sitrep93-covid-19.pdf?sfvrsn=35cf80d7_4

Xiang, Y.-T., Yang, Y., Li, W., Zhang, L., Zhang, Q., Cheung, T., \& Ng, C.H., (2020). Timely mental health care for the 2019 novel coronavirus outbreak is urgently needed. The Lancet Psychiatry 7, 228-229. https://doi.org/10.1016/S2215-0366(20)30046-8 